\title{
Systematic review of pathways to mental health care in Brazil: narrative synthesis of quantitative and qualitative studies
}

\author{
Carlos Eduardo Amaral 1,2,6*(i), Rosana Onocko-Campos ${ }^{1}$, Pedro Renan Santos de Oliveira ${ }^{3}$, \\ Mariana Barbosa Pereira ${ }^{1}$, Éllen Cristina Ricci ${ }^{1}$, Mayrá Lobato Pequeno ${ }^{4}$, Bruno Emerich', \\ Roseléia Carneiro dos Santos ${ }^{4}$ and Graham Thornicroft ${ }^{5}$
}

\begin{abstract}
Background: Pathways to care are actions and strategies employed by individuals in order to get help for healthrelated distress and the related processes of care providers. On several systematic reviews regarding pathways to mental health care (PMHC), studies regarding South American countries were not present. This review synthesizes qualitative and quantitative research about PMHC in Brazil.

Methods: LILACS, MEDLINE and SCIELO databases were searched for papers regarding PMHC in Brazil. The results were organized in pathway stages, based on Goldberg and Huxley's 'model of Levels and Filters' and on Kleinman's framework of 'Popular, Folk and Professional health sectors'. Analysis also considered the changes in national mental health policy over time.

Results: 25 papers were found, with data ranging from 1989 to 2013. Complex social networks were involved in the initial recognition of $\mathrm{MH}$ issues. The preferred points of first contact also varied with the nature and severity of problems. A high proportion of patients is treated in specialized services, including mild cases. There is limited capacity of primary care professionals to identify and treat MH problems, with some improvement from collaborative care in the more recent years. The model for crisis management and acute care remains unclear: scarce evidence was found over the different arrangements used, mostly stressing lack of integration between emergency, hospital and community services and fragile continuity of care.
\end{abstract}

Conclusions: The performance of primary care and the regulation of acute demands, especially crisis management, are the most critical aspects on PMHC. Although primary care performance seems to be improving, the balanced provision and integration between services for adequate acute and long-term care is yet to be achieved.

Keywords: Pathways to care, Clinical pathways, Systematic review, Public health, Mental health policy

\section{Background}

Pathways to care, pathways of care, help-seeking pathways, clinical pathways and therapeutic itineraries are similar (and sometimes overlapping) concepts that refer to the actions and strategies employed by individuals in order to get help for health-related distress [1-5], and/ or the related processes of care providers. The actions

\footnotetext{
*Correspondence: caduamaral@gmail.com

${ }^{6}$ Fortaleza, Ceará CEP 60125-001, Brazil

Full list of author information is available at the end of the article
} 
include attempts to contact other individuals and organizations, both from the formal health system (such as health professionals and services) and other non-statutory agents, such as traditional healers, lay care and social support.

The relevance of clinical presentation, patient choice, system regulation, legitimacy of informal care, and subjective, social and cultural influences on preferred courses of action varies in different definitions of the concept. Vanhaecht et al. [6] identified care pathways as complex interventions, with potential to be used as a model, as a process-oriented improvement strategy or as an ex post facto product for research and evaluation. Evans-Lacko et al. [4] argue that the two essential components on different definitions of pathways to mental health care (PMHC) are the types of services and interventions provided; and a timeline assumption of their provision.

Pescosolido [2] distinguished two approaches in the research on help seeking pathways: the "contingency" approach, that describes and correlates service usage with clinical and sociodemographic profiles of patients, and the "process oriented" view, that focuses on social and interpersonal processes that affect help seeking behaviour in the community and in the health system. Cabral et al. [5] identified three main uses for the concept of therapeutic itineraries: the first focused on patient's perception about illness and how it affects help seeking (patient's viewpoint); another focused on identifying barriers and gaps in health system accessibility and referral arrangements (system's viewpoint); and a third integrative approach that considers patient's actions as part of a socio-economic context that iteratively produces preferred choices and concrete possibilities for both service utilization and informal care (contextual approach).

The characterization of PMHC in the literature can include different ranges of formal and informal care; such pathways might be directed toward specific diagnostic groups or general mental health issues; may be interested in the first contact sought or accessed after feeling distressed, focus on the sources of referral to specialized mental health $(\mathrm{MH})$ care, or trace an exhaustive account of all contacts in retrospective or longitudinal format. The scope of data may be qualitative case studies of an individual's itinerary, provider, city or country-level patterns of service usage or cross-country comparisons [7-11].

A review of pathways in first episode psychosis (FEP) highlighted that the variety of measures used to report the itineraries compromise direct comparison [12]. This overview found that health professionals are usually the first point of contact, and contact with non-statutory agencies is rare, but in both settings the delay until appropriate care is achieved is considerable. The study also concluded that the cultural determination of pathways of care has not been supported by robust evidence.

Other more recent review of FEP pathways found that physicians were the most common points of first contact, but the most frequent referral source to $\mathrm{MH}$ care were emergency services [13]. The review found inconsistent evidence regarding the effects of gender, colour/ethnicity and socio-economic indicators both on the point of first contact and the referral source to specialized $\mathrm{MH}$ care. These findings differed both between and within countries. The same inconsistencies also applied to putative associations between longer duration of untreated psychosis (DUP) and place of first contact or referral source.

A review of eight studies using the World Health Organization Encounter Form performed a meta-synthesis on the information of pathways to care for all mental disorders for 23 countries [11]. The paper analysed the time from onset of the $\mathrm{MH}$ problem to initial search for care, time until first psychiatric care, self-referral rate to psychiatric services, diagnosis, and main point of access to psychiatric care. However, the results varied greatly depending on context, due to differences in health systems' design, service provision and cultural values.

There were no studies from Brazil or any other South American country reported in the three reviews cited [11-13], and Mexico and Cuba were the only Latin American countries reporting data, both from the same cross cultural study [8]. This demonstrates a knowledge gap about pathways in Latin America, including Brazil.

\section{Brazil's mental health system and polices}

Brazil is a higher middle income country, with a GDP per capita of $U \$ 8700$ [14], a population around 200 million in 2017 [15] and extremely high income inequality, with a 51.3 GINI index [16]. The country is divided in five regions, with the Southeast and South regions being more economically developed than the North and Northeast regions, which in turn also have worse Human Development Indices.

Since 1988 the country has had a universal health system, but with a strong presence of the private sector in health care. Around $25 \%$ of the population have private health insurance [17], but there is usually a mixed usage of public and private services [18]. There has been a consistent investment in primary health care in the public sector, with a national coverage rate in 2017 of $74 \%$ of the population, but with severe regional disparities [19].

Mental health care is part of the public health system, being primarily community-based, with diminishing presence of psychiatric hospitals. MH policy has suffered major changes in the past four decades. Until the 1980s the MH system was based primarily in psychiatric 
hospitals, supported by ambulatory care. In the following years, a growing social movement leaded by professionals' and patient's associations began to question the ethics and efficacy of the asylum-based model, exposing widespread human rights violations occurring inside psychiatric hospitals [20]. Those actions developed into the Brazilian Psychiatric Reform movement, and in 1987 the first "experimental" community services were created. In 1992 a regulation from the National Ministry of Health made community $\mathrm{MH}$ services (Centros de Atenção Psicossocial-CAPS) a national policy, and in 2001 a federal law prohibited the creation of new beds in psychiatric hospitals, in order to force a shift in the federal budget towards community services.

In 2006, for the first time the MH budget ratio favoured community care, with $56 \%$ of the allocated federal budget, showing a steady increase and reaching $79 \%$ in 2013. In 2008 a policy created teams to support primary care staff (Núcleos de Apoio à Saúde da Família-NASF) with professionals from different specialties, including MH. From 2011 onwards integrated MH care networks were officially advocated by federal government policies (Redes de Atenção Psicossocial), encouraging service integration and variability on the different provider levels (municipal, state and federal levels).

Although CAPS and NASF are currently the main services in the national policy, there are also other services that provide ambulatory care, independently or integrated with psychiatric hospitals. $\mathrm{MH}$ crisis are handled primarily in psychiatric hospitals, psychiatric units in general hospitals and in a specific category of 24-h community MH services (type III CAPS). While there are national and local mental health policies, the State has weak regulatory power over the way the services perform, prevailing autonomy in clinical practice. These aspects, along with insufficient service coverage, cause a lot of variability on service availability and singular patterns of MH itineraries in each municipality.

The objective of this review was to explore the characteristics of pathways to mental health care in Brazil, synthesizing evidence from published quantitative and qualitative research. The specific objectives were to articulate the results with different national $\mathrm{MH}$ policies adopted over time, and to highlight evidence for each pathway stage.

\section{Methods}

A large variety of study methods and designs addressing PMHC have been used, including qualitative and quantitative studies. Since the PMHCs have considerable sensitivity to context, such broad approach is surely beneficial. However, the traditional systematic review methods would not suffice in analysing and integrating such diversity. Therefore, we used a narrative synthesis, in which a narrative approach is used to integrate evidence, since a statistical approach would be insufficient to handle the results from all relevant sources [21].

The initial search was performed in LILACS, MEDLINE and SCIELO databases, from August to December 2017. Additional file 1 presents details on the search strategies.

The search had no date or language restrictions; included empirical studies using any method or design, either exclusively on MH conditions or at least with separate data and discussion for those conditions, on any age group, performed integrally or partially in Brazil. Studies of any mental disorder were included, encompassing severe and common mental disorders, psychiatric/psychological symptoms, mental suffering, autism and Alzheimer. However, substance abuse, mental paralysis and mental retardation were excluded, since there is a much different array of health services destined specifically for these conditions. Although autism is a developmental disorder, the specialized services for such condition in Brazil are usually child and adolescent community $\mathrm{MH}$ services, whereas other developmental disorders, such as mental retardation, are less frequently addressed on those services. Papers that mentioned substance abuse as a co-occurring condition to other $\mathrm{MH}$ problems in the inclusion criteria were considered.

Studies of informal or folk care providers were included only if the study authors or participants explicitly matched the nature of the distress with a $\mathrm{MH}$ condition described in the inclusion criteria. The screening also considered the following subthemes associated with the concept of PMHC: access; accessibility; globality, continuity of care; and service integration. Additional file 2 details the inclusion and exclusion.

Each study was screened for title and abstract by a pair of independent reviewers (either MLP and BE, or MBP and ECR), and the full text assessment was done by a new pair of reviewers (either PRO and MLP, or CEA and RS). In each stage, any disagreements were settled by independent assessment from a member of the other revision pair.

Quality appraisal was performed using the appropriate Critical Appraisal Skills Program (CASP) checklists, according to each study's design. One qualitative study was discarded for missing essential information on the description of the research scenario, sampling methods and analysis framework.

\section{Data analysis}

The studies were categorized based on an adaptation of the Levels and Filters Model, originally designed by Goldberg and Huxley [1]. The original model describes 
the pathway between the community and specialized $\mathrm{MH}$ care, with some events being considered filters to move from one level to the next. The first level would be the existing morbity in the community. The second level comprises all the people with $\mathrm{MH}$ issues that make contact with a primary care service, while the third level represents the group with conspicuous $\mathrm{MH}$ issues. The fourth level are the people referred to specialized $\mathrm{MH}$ care, and the last level would be the group actually receiving specialized care [22].

The path from the community until specialized care would have the following series of filters: the decision by the patient to seek medical help; the recognition of a $\mathrm{MH}$ problem by the general practitioner (GP); the decision by the GP to provide care or refer to specialized care; the decision by the psychiatrist to provide care. The model highlights that the majority of patients with $\mathrm{MH}$ issues is seen in the first level, and a minority, consisting mostly of severe cases, in the last levels $[1,22]$.

The stages of the model are complementary, although when analysed separately they might shed light in important barriers to mental health care. However, a few modifications on the model were necessary for analytical purposes and adaptation to the Brazilian context. We had to dismiss the notion of primary care as the first logical step in the patient's decision to consult, and acknowledge instead the decision of where to look for care. This proved useful to analyse the frequent paths with direct access to the community health teams or referrals from hospitals.
Secondly, we considered relevant to include other sources of care besides the formal health system. In this aspect, Kleinman's framework [23] of a health system comprised of the professional, folk and popular sectors seemed appropriate to organize our data.

Kleinman highlights the cultural and symbolic outlines in treatment and healing experiences of different peoples, stressing how medical interventions are not the only options to be sought and legitimated by people in distress. Instead, the author identifies the coexistence of treatments, rituals and traditions that people submit to, usually seeking more than one type of healing agent. In light of this, Kleinman proposes an explanatory model that integrates those different cultural agents, including not only the formal health professionals, but also the contact with other cultural experts and participation on popular traditions as part of one's therapeutic itinerary [23].

Finally, on a final addition on our framework, we gave more relevance to the family role in the initial stages of help seeking, in order to address some criticism regarding the Levels and Filter's model inadequately explaining patients' behaviour when refusing care [12].

Therefore, we added a stage consisting of the decisions by patients (or their families) to seek care from different agents, which may include, in addition to the formal health system, religious and secular healers, self-help and peer-support strategies, family members and other forms of social support. The overview of the adapted model can be seen in the Fig. 1.

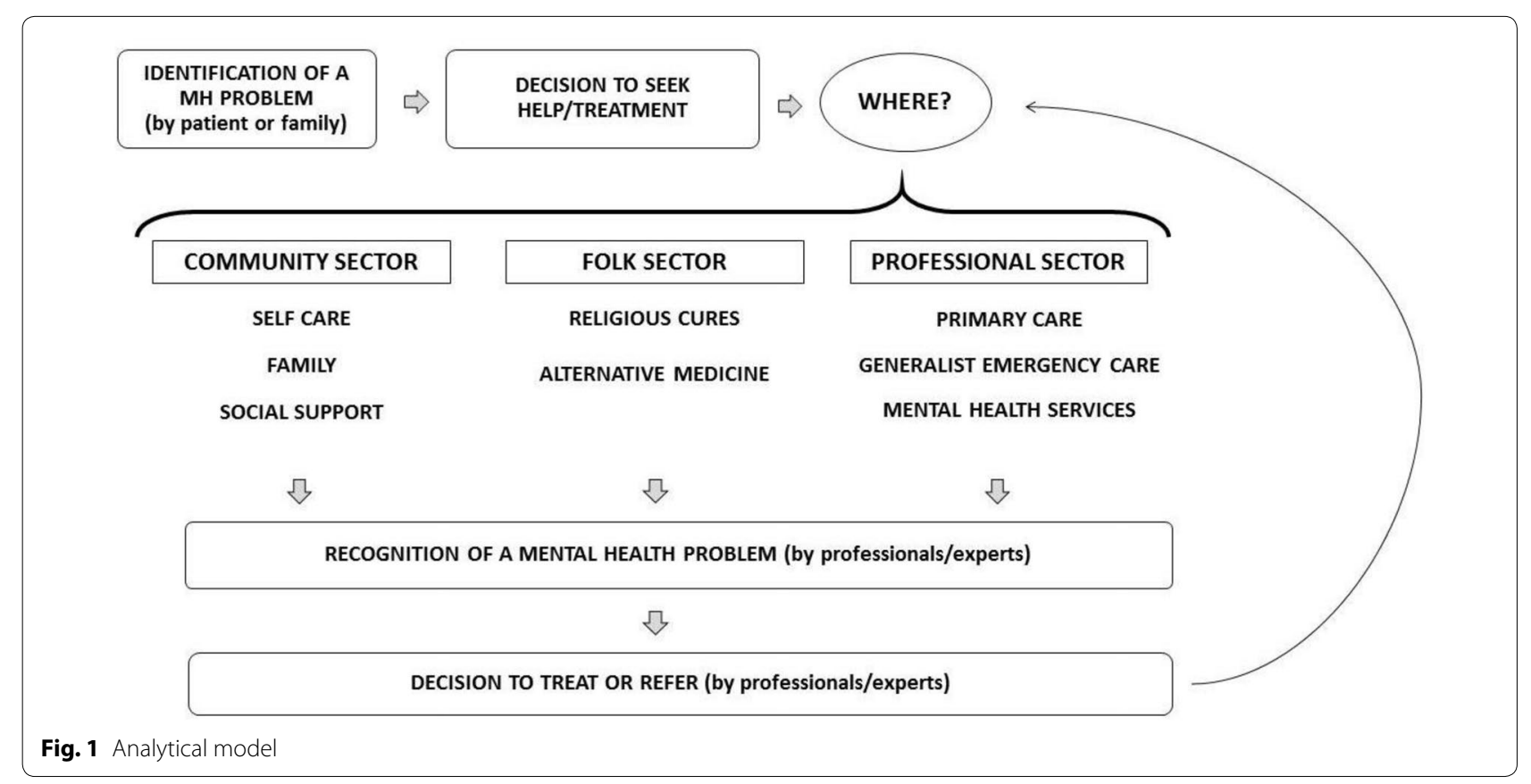


The model allowed relevant data of the reviewed studies to be aggregated and compared within each stage. In addition, challenges and improvements addressed to each filter, as reported by results of individual studies, were synthetized, compared and discussed in the light of the targeted goals of $\mathrm{MH}$ policies in place during the period.

Each study provided data for at least one stage, but inclusion in more than one stage was also possible. Data regarding the studies' dates, methods and scenarios (cities and health services involved, and other places of care, if applicable) were also extracted, as well as targeted diagnosis and age groups, when applicable.

\section{Results}

The initial search strategy identified 326 references, which 241 remained after duplicate removal. After title and abstract screening 40 papers were considered in full text assessment, and 21 studies were to be included, but one was discarded for poor quality. The references of these papers were screened for additional studies; experts and authors of studies that appeared to have additional data of interest were contacted. After this process five additional sources were included. See Fig. 2 for the complete flowchart. Authors were also contacted to clarify the period of data collection when the papers did not provide clear information.

The studies ranged widely in terms of design and objectives. Several definitions of pathways to care were found, but there was no usage of any standardized measures. The papers also varied regarding the objectives: most did not have the description of the pathway of care as main goal, but data of interest for one or more stages of our analytical model.

Out of the 25 studies, 9 were quantitative $(7$ crosssectional and 2 longitudinal designs), 14 were qualitative and 2 were mixed-methods. All qualitative studies used individual interviews for data collection. As additional sources, 2 studies also used focus groups and 2 performed participant observation.

The papers were published between 1999 and 2017. The studies' data collection period ranged from 1989 to 2013 , and nearly all studies $(n=23)$ were performed after

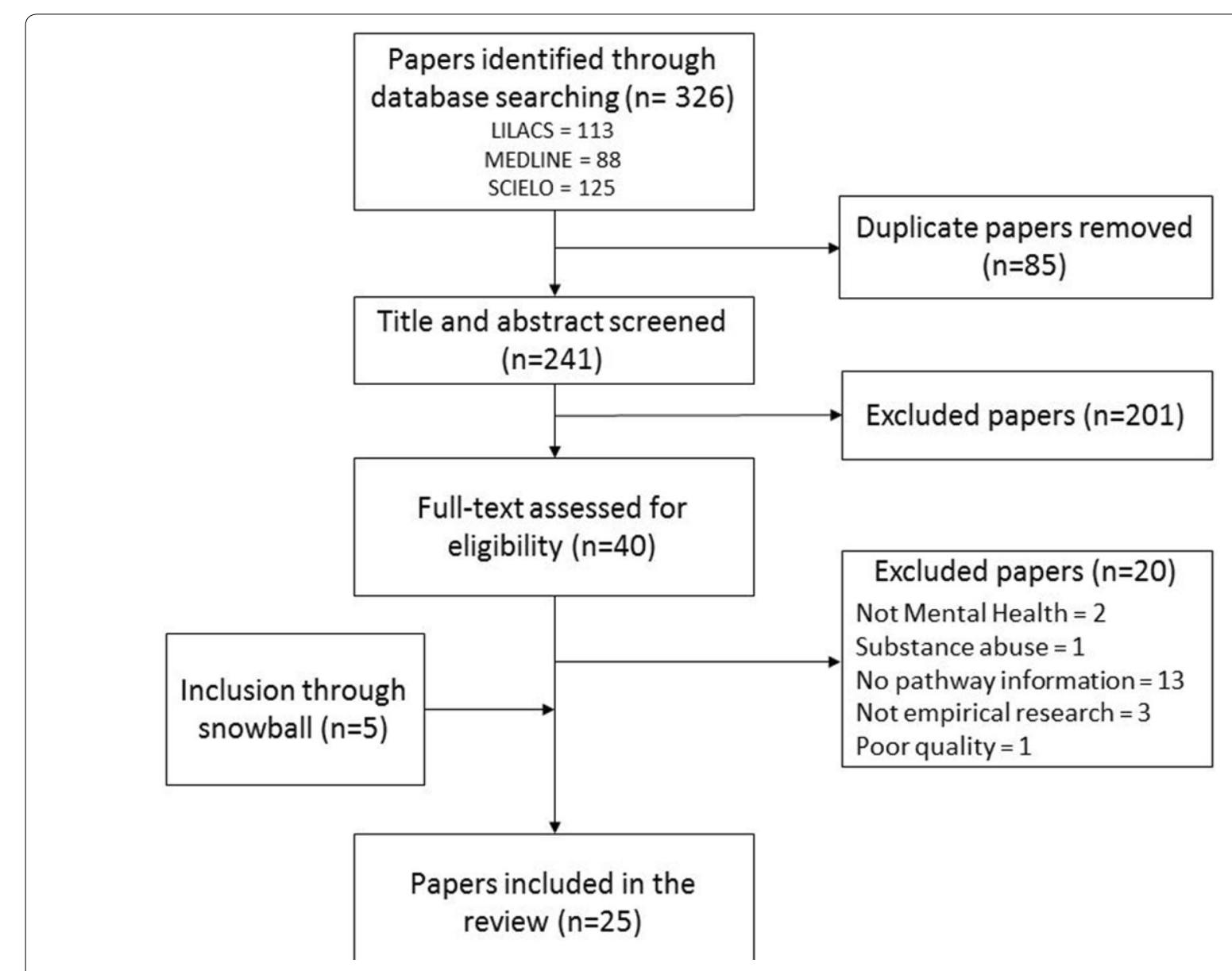

Fig. 2 Study selection flowchart 
2001, when the Psychiatric Reform Law was signed. Over a third of the studies occurred after the Mental Health Integrated Networks policy was approved, and a single study pre-dates the CAPS' national policy, approved in 1992. The distribution of the studies per year and $\mathrm{MH}$ policy period is available in Additional file 3.

In total, evidence from at least 26 cities was provided, with 15 municipalities located in the southeast region, and 11 of those specifically in the state of São Paulo. This concentration is due to one study that targeted 8 different cities in this state. The city of São Paulo, capital of the State of São Paulo, was the most studied municipality (8 papers), which can be explained by the city's relevance as Brazil's major economic, scientific and populational centre. A single study from the North region was found, in one city. Some studies did not disclose the city or cities researched. Only 7 papers reported local service provision, in order to provide better context for the findings. Data on research scenarios can be found in Table 1, and the sources of data extraction for each pathway stage can be found in Table 2 .

\section{Recognition of the mental health problem by the patient or family}

A study in 2007 identified that only $59 \%$ of parents of children with persistent $\mathrm{MH}$ problems considered $\mathrm{MH}$ treatment was needed [31]. Two studies on autism highlight the family role in identifying the initial symptoms, especially by the comparison with other children of similar age in order to discriminate delays in speech development and social isolation $[32,46]$.

Identification by family members is also reported in studies about eating disorders $[33,42]$, which stress the

\begin{tabular}{|c|c|c|c|}
\hline Region $^{a}$ & State $^{\mathbf{b}}$ & $\begin{array}{l}\text { Number } \\
\text { of researched cities }\end{array}$ & Studies' references \\
\hline N & AM & 1 & {$[24]$} \\
\hline \multirow[t]{2}{*}{ NE } & BA & 1 & {$[25]$} \\
\hline & CE & 3 & {$[24,26,27]$} \\
\hline \multirow[t]{3}{*}{$C W$} & DF & 1 & {$[28]$} \\
\hline & $\mathrm{GO}$ & 1 & {$[24]$} \\
\hline & MT & 1 & {$[29,30]$} \\
\hline \multirow[t]{3}{*}{ SE } & SP & 11 & {$[26,31-39]$} \\
\hline & RJ & 2 & {$[26,40,41]$} \\
\hline & $M G$ & 2 & {$[24,42,43]$} \\
\hline S & RS & 3 & {$[44,45]$} \\
\hline
\end{tabular}

a N: North; NE: Northeast; CW: Center-West; SE: Southwest; S: South

b AM: Amazonas; BA: Bahia; CE: Ceará; DF: Distrito Federal; GO: Goiás; MT: Mato Grosso; SP: São Paulo; RJ: Rio de Janeiro; MG: Minas Gerais; RS: Rio Grande do Sul role of mothers of anorexic or bulimic youths in noticing behaviours such as food selectivity and severe weight loss. However, one of these studies also highlights how people with anorexic or bulimic behaviours do not acknowledge their eating habits or body image perception as inadequate or pathological, showing a conflicting interpretation of their experience in comparison with their families' and other carers' [42].

Expectation that schools should take a greater role identifying and treating children and adolescents with mental health issues is reported by parents whose kids have been treated in primary care [26] or child and adolescent community mental health services (CAPSi) [34]. Both studies report that parents consider schools as the most propitious setting to identify early symptoms.

A case study, done in 2012 in Rio de Janeiro, describes an adolescent whose family considered her first mental health crisis as a religious experience [40]. This idea was only dismissed after an encounter with a protestant preacher, who identified it as a health condition. However, only after a second crisis, which led to a psychiatric admittance, that the experience was considered a psychotic episode. Another study done in Rio de Janeiro in 2013, with members of the Candomble Afro-Brazilian religion [41], describe a shared sense of belonging, empathy and identification among those that join the religion searching for support for mental distress. The study indicates that although the religion provides care and an explanatory system for the suffering, its members and religious leaders strongly assert the medical perspective as a complementary (and not conflicting) framework of explanation and treatment.

\section{Decision to seek help and choice of care Children and adolescents}

A research done in 1989 in five cities in the São Paulo metropolitan region [35] with children and adolescents with "nervous issues" (problema dos nervos), found 141 cases, but only $18 \%$ had sought help. From the ones that sought help, 56\% (19 cases) contacted a GP, informal help was contacted in $6(22 \%)$ cases, and psychologists in 2 cases. Churches and school were not mentioned as sources of help. Among the cases that did not seek any type of help (109 cases), 61 (56\%) considered help was not necessary; 2 referred difficulties to get medical or psychological consultations; and 10 referred "lack of time", which might also indicate an access barrier to specialized care.

A cohort study in one municipality of São Paulo state [31] identified 124 cases of children (aged 6-13) with $\mathrm{MH}$ issues (from a representative sample of 345 children) in 2002. Five years later the sample was reassessed, and 32 cases were identified with persistent $\mathrm{MH}$ problems, 16 
Table 2 Data extraction for each pathway stage

\begin{tabular}{|c|c|c|c|c|c|c|c|c|}
\hline \multirow[b]{2}{*}{$\begin{array}{l}\text { Subtheme } \\
\text { Articles }\end{array}$} & \multirow{2}{*}{$\begin{array}{l}\text { Recognition of } \mathrm{MH} \\
\text { problem (by patient } \\
\text { or family) }\end{array}$} & \multicolumn{2}{|c|}{$\begin{array}{l}\text { Decision to seek help } \\
\text { and choice of care }\end{array}$} & \multirow{2}{*}{$\begin{array}{l}\text { Recognition } \\
\text { of the MH (GP } \\
\text { or other non- } \\
\text { specialist) }\end{array}$} & \multicolumn{4}{|c|}{$\begin{array}{l}\text { Decision to treat or refer (by GP, other general health } \\
\text { services or specialized services) }\end{array}$} \\
\hline & & $\begin{array}{l}\text { Children } \\
\text { and adolescents }\end{array}$ & Adults & & Primary care & $\begin{array}{l}\text { General } \\
\text { health } \\
\text { services }\end{array}$ & $\begin{array}{l}\text { Specialized } \\
\text { services }\end{array}$ & $\begin{array}{l}\text { Service } \\
\text { integration }\end{array}$ \\
\hline [24] & & $x$ & & & & & & \\
\hline [25] & & & $x$ & & & & & $x$ \\
\hline [26] & $\times$ & $x$ & & & $x$ & & & \\
\hline [27] & & & & $\times$ & $\times$ & & $x$ & \\
\hline [28] & & & $\times$ & & $\times$ & & & \\
\hline [29] & & & $\times$ & & & & & \\
\hline [30] & & & & $\times$ & $\times$ & & & \\
\hline [31] & $\times$ & $x$ & & & & & & \\
\hline [32] & $x$ & $x$ & & $x$ & & & & \\
\hline [33] & $\times$ & & $\times$ & $\times$ & & & & \\
\hline [34] & $\times$ & $x$ & & & & & $x$ & \\
\hline [35] & & $x$ & & & & & & \\
\hline [36] & & & $\times$ & & & & & \\
\hline [37] & & & $\times$ & & & & & \\
\hline [38] & & & & $\times$ & & & & $x$ \\
\hline [39] & & & & & & $\times$ & & \\
\hline [40] & $\times$ & $x$ & & & & & $x$ & $x$ \\
\hline [41] & $\times$ & & $\times$ & & & & & \\
\hline [42] & $\times$ & & $\times$ & & $\times$ & & & \\
\hline [43] & & & & & $\times$ & & $x$ & \\
\hline [44] & & & $\times$ & & & & & \\
\hline [45] & & & $x$ & & $x$ & & $x$ & $x$ \\
\hline$[46]$ & $\times$ & $x$ & & $\times$ & & & & \\
\hline [47] & & & & & & $x$ & & \\
\hline [48] & & & & & & & $x$ & \\
\hline Total & 9 & 8 & 10 & 6 & 7 & 2 & 6 & 4 \\
\hline
\end{tabular}

(50\%) had sought treatment, and only 12 (38\%) obtained it.

An qualitative inquiry [34] with children and adolescents in treatment at CAPSi in the city of São Paulo revealed that parents face several access barriers during the treatment period, causing treatment abandonment and, hereafter, new searches for help at the same services.

Studies with autistic children highlighted the difficulty to obtain a correct diagnosis, being frequent to visit several health services (primary and specialized care) until the diagnosis is confirmed $[32,46]$.

A community-level inquiry with children and adolescents with psychiatric disorders [24] identified that $20 \%$ of cases with $\mathrm{MH}$ issues had used $\mathrm{MH}$ providers in the previous 12 months, although the study did not discriminate types of services. The vast majority was seen by psychologists $(84.9 \%)$, in comparison to $20.9 \%$ consulted by psychiatrists and $18.8 \%$ by neurologists (several people were seen by more than one type of professional).

Adolescents consulted in primary care centres reported solving problems generally on their own or among peers [26]. They mostly did not see clinics, their family, or other institutions as sources of help. Their parents also did not identify primary care centres as a place to look for $\mathrm{MH}$ assistance. Parents felt discouraged by long queues and perceived staff as rushed and uninterested, and generally sought help elsewhere: cardiologists or neurologists (since emotional and behavioural problems could represent problems of the "heart" or "nerves"); friends and neighbours; and religious leaders, such as evangelical pastors and Catholic priests, both for direct advice and referrals. The latter is similar to a case study of an adolescent with severe mental issues [40] that was taken first to a religious temple, subsequently had several intermittent 
contacts in psychiatric emergency services, until commencing a long-term treatment at a CAPSi.

\section{Adults}

A research identified help seeking behaviours for three mental health symptoms: anxiousness, insomnia and depressive mood [36]. The vast majority did nothing to address the symptoms, with $6 \%$ seeking medical help for anxiousness, $5 \%$ for insomnia and $7 \%$ for depressive mood. Seeking consultation was less frequent than selfmedication for all symptoms $(15 \%, 12 \%$ and $10 \%$, respectively). Women had higher percentages than men for both self-medication and consultation.

The preferences of the general public on help seeking for Alzheimer symptoms registered as first choices close family (27\%), psychologist (15\%), neurologist (13\%), selfhelp group (12\%), general practitioner (12\%), close friend (9\%) and psychiatrist (8\%) [29]. Religious leaders, faith healers and pharmacists were rarely selected as a first choice of help. A case study with an elderly woman with a inconclusive Alzheimer diagnosis reported emergency services as the places first sought for help, afterwards $\mathrm{MH}$ professionals (several psychiatrists, a neurologist and a psychologist) became the preferred points of contact [44].

In relation to FEP, a cross-sectional research in the city of São Paulo [37] identified that most cases sought help in psychiatric emergency services (74\%), and only $26 \%$ sought outpatient services. The study also found a very short median DUP (4.1 weeks), attributed to beneficial living arrangements (co-habitation with close relatives) and good emergency service coverage.

Diagnosis and treatment are usually refused by people with eating disorders, therefore the initial contact with the health system is made by the families rather than the patients [42]. In regard of types of professional contacted, out of 21 patients interviewed, 11 looked for medical doctors, 7 went first to psychologists and 2 sought nutritionists. Another study about anorexia from 2012 [33] reports that some mothers went initially to emergency services, after their daughters' severe malnutrition required hospital admittance.

Although some evidence points to religious figures referring to the formal health system, for most adults from the Candomble religion, the reverse itinerary happened: the formal health system was the first choice for help, and only after the help provided was deemed insufficient that the religious agencies were sought [41]. The religious leaders strongly recommended going through the formal health system beforehand.

Two qualitative papers, with health managers [45] and primary health care workers [28], stress the absence of integrated clinical pathways, usually being left to the patients to control and decide their itinerary in the health system. The studies also reported that different services provide intermittent care, without any provider being able to offer longitudinal follow-up. The health managers describe four main access points for patients seeking $\mathrm{MH}$ support: primary care, CAPS, MH ambulatories and hospitals; but since only the hospital has effective response to unscheduled demands, it has the strongest regulatory influence in the clinical pathways [45].

\section{Recognition of the mental health problem by GP or other general health services}

According to a qualitative research with primary care professionals [30], mental health demands are invisible in this level of care: $\mathrm{MH}$ issues are frequently not identified nor diagnosed, and the few detected patients have no medical record in the primary care centres. Another study [38] highlights the difficulty for primary care to identify $\mathrm{MH}$ demands in homeless people, being dependent on other support teams to approach this group.

Two papers about autism [32, 46] stress that primary care usually is the first contact, but paediatricians and nurses frequently fail to identify the child's behaviour changes. Difficulty on diagnosis is also reported in one study about eating disorders [33], in which mothers claim that symptoms of anorexia were frequently considered mere "whim" by doctors.

One study [27] reports on the effect of mental health matrix support teams, which allowed primary care workers to better understand mental health disorders. Consequently, identification and treatment of those patients became more frequent, including care to patients with physical problems that had psychological or social determinants or comorbities previously ignored by the health staff.

\section{Decision to treat or refer: by GP, other general health services and specialized services Primary care}

Six qualitative studies identified limited capacity of primary care professionals to treat mental health issues, highlighting referrals to specialized care as the most common practice [26-28, 30, 42, 45]. A qualitative study done in 2005 [26] in three major Brazilian cities reported that primary care professionals tend to offer mental health care only when they perceive referral as impossible due to access barriers. In such cases, they usually performed counselling more based on common sense than on specific training. Another study from 2005, in Cuiabá [30], identified the mental health practices in primary care as either solely medication, or improvised actions. Similarly, in a study form 2008 with primary care staff in the city of Brazlândia-DF [28] the reported mental health 
interventions were only chatting and guidance, presenting very limited efficacy and frequently needing to refer to psychiatric services.

A study from 2011 done in Fortaleza and Sobral (CE) [27] identified prescription of psychiatric drugs and engaging organized community social resources as mental health actions supported by matrix support teams. A study in 2013 with bulimic and anorexic patients highlights actions from generalist doctors to establish shared case management with psychiatrists, psychologists and nutritionists to provide adequate care [42].

A single study, in Belo Horizonte-MG in 2003, evaluated the de-escalation of care [43], investigating adults with mental disorder that were referred to primary care by a community MH service. The study found that $36 \%$ of patients referred after treatment never reached primary care. From the patients actually seen in primary care, even fewer remained in treatment at 9-month follow up (60\% of those who reached PHC, and 39\% of the initially referred). Referred patients that did not completely cease contact with the specialized $\mathrm{MH}$ service after referral had higher odds of successful continuity, both for reaching and maintaining contact with primary care.

\section{General health services}

A study in São Paulo metropolitan area identified patterns of service use according to different diagnosis (anxiety, mood and substance user disorders), reporting low contact with the folk sector ( $6 \%$ of cases), and increased contact with formal healthcare (24\% of cases). From the segment seen in the professional health sector, $70 \%$ attended specialized services and $40 \%$ generalist services (treatment at both services was possible). Those proportions were similar among each diagnosis within the anxiety and mood disorders group, but not for substance use, which showed an ever higher proportion of specialized service usage ( $90 \%$ vs. $15 \%$ of general health services) [47]. Another study from the same research [39] identified that around $40 \%$ of cases of $\mathrm{MH}$ issues treated in general health services received only medication, while a minority (9\%) received a combination of medication and psychotherapy. The proportion of medication-only treatment at specialized services was similar, but the combined treatment was much higher (23\%).

\section{Specialized services}

A study done in 1998 in a community mental health service in Belo Horizonte [43] identified that $17 \%$ of their patients came from spontaneous demand, while 30\% were referred by primary care, $26 \%$ from psychiatric hospitals and $27 \%$ from other services.

The "open-doors" policy in the community MH services is highlighted as an ideological principle in a study with CAPS professionals [48], who state that granting initial access to the mental health system through this service is a strategy to strengthen the communitybased $\mathrm{MH}$ care model and consolidate the change from the previous hospital-based model. However, engaging an actual treatment follow certain protocols to assess severity. Nevertheless, another study [27] stresses how CAPS professionals feel there are excessive inadequate referrals from primary care that overcrowd the CAPS services. One qualitative study with parents of children and adolescents treated in infant and adolescent CAPS [34] points out that, after the initial assessment at these services, several parents gave up due to a long waiting period for the treatment to start.

Although the open-door principle is part of the official CAPS policy, not all services are able to offer unscheduled appointments at a reasonable rate, making the general hospital the first choice for the initial treatment in some cities. This was shown both in a qualitative study with health managers of Santa Maria-RS in 2008 [45] and a case study with an adolescent in the metropolitan region of Rio de Janeiro-RJ in 2012 [40].

\section{Service integration}

Several studies highlight the difficulty to integrate care between services, once the patients have started treatment. Emergency MH care provided by hospitals is seen as discontinuous and lacking communication with the remaining $\mathrm{MH}$ system, which in turn is also seen as fragmented, unable to guarantee continuity of care, and with loose regulation of planned patient flow [25, 38, 40,45].

\section{Discussion}

Complex social networks were involved in the initial recognition of $\mathrm{MH}$ issues and the preferred points of first contact varied with the nature and severity of problems. A high proportion of patients is seen in specialized services, including mild cases. There is limited capacity of primary care professionals to identify and treat $\mathrm{MH}$ problems, with some improvement from collaborative care in the more recent years. The model for crisis management remains unclear: scarce evidence was found over the different arrangements used, mostly stressing lack of integration between emergency, hospital and community services and fragile continuity of care.

We identified an important role of social networks supporting the recognition of mental health issues. Besides the self-perception by the person in suffering, other agents such as family, religious agencies and schools were identified as determinants when distinguishing mental health problems.

The studies included in this literature review show that religious figures have an important role not only in 
offering religious cures and social support, but also in re-directing people to health services. This aspect differs from reports from other middle income countries like Mexico and Cuba, where the search for religious agencies for mental disorders appears scarce [12], but is similar to India, Indonesia and South Africa where religious healers are common in PMHC $[11,49]$.

The notion of mental suffering originating from magical-religious causes is still common in Brazil; religion and mental health/illness have a profound cultural and historical association [50]. Nowadays the offer of religious cures is not as common anymore in Catholicism, Brazil's largest denomination. However, it is still quite usual in the other main religions, such as Protestantism, Spiritism, Candomble and Umbanda. The role of religious agencies is also highly valued in Brazil as a coping strategy, consistent with other Latin-American countries, as well as Latin migrants in other countries [51].

No association has been found between religions and DUP, and different explanatory models (medical and spiritual) seemed to co-exist as complementary in most reports. This differs from evidence from South Africa, where pathways starting from religious healers showed longer DUP and more stages until reaching formal $\mathrm{MH}$ care.

Concerning children and adolescent mental health problems, as well as adults with eating or psychotic disorders, family appeared as an important factor on problem identification, decision to seek care and definition of the initial source of help. A considerable short DUP for FEP was found in São Paulo (4.1 weeks), in comparison with international evidence (4-68 weeks, with a within study median of 21.6 weeks) [13]. This appears to be related to the active family role on help-seeking in Brazil, as family support has already been reported as an determining factor to shorten DUP [52, 53]. Studies with Latino populations in the United States have also showed that familismo, as a strong Latin-American value, influences individuals to give emphasis on family-level communication, which in turn affects the subsequent help-seeking choices [51].

Nevertheless, there is an apparent conflict of evidence of low frequency of help seeking for children and adolescents with MH issues: $18 \%$ of cases with "nervous issues", reported in 1989; $50 \%$ of cases with persistent problems in 2003. The studies address problems with different severities, on distinct periods and cities, but neither report mental health services availability. However, other recent studies in the review reported long waiting periods as access barriers in both primary care and infant and youth community mental health services.

Therefore, between the patients' decision to seek treatment and the health professional's decision to treat there might be decisive accessibility issues conditioning these individual decisions, highlighting the importance of a contextual approach [5] when analysing the Brazilian pathways of care. The apparent low frequency of helpseeking for children and adolescent $\mathrm{MH}$ issues needs to be contextualized in a scenario of insufficient offer of care $[54,55]$. Additionally, hyper-medicalization of common infancy and youth situations, creates an artificial inflation of mental health demands [56, 57].

The choice of the initial help seeking contact seems to vary accordingly to the type of $\mathrm{MH}$ demand present. Unspecified symptoms of anxiety, insomnia and depressive mood rarely trigger help seeking on health services, with self-medication being much more common. The studies addressing eating disorders and mental health problems in children and adolescents, report general health services as first contact, while for FEP psychiatric emergency services were the first choice. Studies in different countries also identified divergences in help seeking behaviour according to diagnosis and symptom severity $[58,59]$.

Identification and treatment of $\mathrm{MH}$ problems in primary care and in other general health services are highlighted as challenges in several studies. Neglect and disdain for $\mathrm{MH}$ issues, as well as the nature of some interventions, are a cause of concern. The report of actions from primary care teams grounded solely on common sense or exclusively medication-oriented reveal significant limitations. However, a positive impact seems to be happening after investments by the Health Ministry and local health authorities $[60,61]$. The more recent studies in the review stress specially the effects of specialized matrix support, from NASF teams and other collaborative care configurations, though studies from after the implementation of NASF teams also report difficulties to adequately address $\mathrm{MH}$ in primary care.

The beneficial effects of collaborative care reported include improvements in identification of $\mathrm{MH}$ issues, quality of drug prescription, engagement of community resources and shared case management. Other effects reported on the Brazilian literature are increased access to primary care, more adequate referrals to specialized care, support for individual and group psychotherapy, and reduction on stigma [62-65]. International literature points to good outcomes in shared management of depression, mixed results in psychosis and substance abuse and a dearth of studies in anxiety, personality and eating disorders [66].

Continuity of care is a critical issue when referring patients from specialized care back to primary care, as few people seem to reach the primary centres after referral, and fewer adhere to long term follow up. Even in the more recent studies, service integration continues to 
be a major issue. The definition of the adequate level of case complexity for primary care is also debatable, lacking consensus by NASF professionals and primary care teams [67].

Only a single study, done in the city of Belo Horizonte in 1998, reported the proportion of different referral sources to the CAPS [43]. Therefore, a historical or regional comparison within Brazil was not possible. The found rate of direct access to the CAPS (17\%) was similar to the rates to specialized $\mathrm{MH}$ care in other middle-income countries (MIC), such as Bangladesh, Bulgaria, India and Indonesia [11]. The proportion of access from GP referrals (30\%) was considerable higher than in South Africa (4\%) [49], another MIC, but much lower than in Cuba, Spain and the UK (70-85\%), middle and high income countries with a strong gatekeeping role by primary care and very low percentage of direct access $(0-2.5 \%)$ [11].

Although in a stepped care model the access to specialized services should be mediated by primary care, the current mental health system in Brazil was designed with direct access to mental health services, especially to the CAPS. While the gatekeeping role of GPs should ensure high rates of early detection, it can also increase the delay in reaching proper mental health treatment [11]. Additionally, CAPS professionals have been frequently reporting an excessive amount of low-complexity demands at the specialized level, which increases case load and precludes adequate intensity of care for the more severe cases [62-64, 68].

Indeed, the proportion of treated cases that use specialized services is quite high (70\%) [39]. Reports on 12-month service use for anxiety, mood, and substance disorders shows that, in high income countries, $37-52 \%$ of cases were seen in specialist services, where in middle income countries the proportion varied from $16-54 \%$ of the treated cases [69].

Health system organization and professional practice characteristics might be the main predictors for choice and frequency of professional consultation, instead of patient need profiles [70]. Our review shows a lack of service integration in Brazil, in a context of weak regulatory power from health authorities, despite recommendations on an integrated mental health networks policy. Also, the mix of public and private providers in Brazil reinforce health inequities and contribute to increased patient discretion on the pathways of care [18].

General hospitals and emergency services (some of them at psychiatric hospitals) appear to have better accessibility for unscheduled demands, in comparison to most CAPS services. This seems to provide a stronger regulatory power to these services on crisis management and other acute situations, despite being fewer services and having an overall lower volume of patients than the CAPS. Although the integrated care networks policy describes type III CAPS as priority services for managing acute episodes, it also includes both emergency services and primary care centres as planned points of first contact and risk assessment. The model for acute care remains unclear and under pressing debate in Brazil, with claims of emergency services being either central devices for the Psychiatric Reform [71] or reminiscent of the previous asylum-based model [72].

The review also lacked studies focusing on broader aspects of pathways involving psychiatric hospitals. Those services still receive a large volume of patients since the availability of type III CAPS and psychiatric units in general hospitals is utterly insufficient. Scarce evidence over the different models on acute care in Brazil was provided in the reviewed papers.

\section{Limitations}

Although, to the best of our knowledge, this is the first study to review literature on pathways to mental health care in Brazil, as well as the first review to use the progression of national policies over time to compare studies from different periods, this review has some limitations. First, the patterns of PMHC in Brazil seem very dependent of local contextual factors, especially on the provision of different types of services and the possibility of integrated care between them. The lack of comprehensive data on a wider range of settings prevents conclusive reports on nation-wide impacts of the policies. This issue is likely present in other studies of pathways of care in different countries, although the literature tends to generalize evidence from few local sites as national configurations. This might hide important differences in those patterns, which can be a particularly serious problem in a large and unequal country such as Brazil.

A second limitation is that only the qualitative studies included in the review had the analysis of pathways of care as main research objectives, while the quantitative studies provided reports on specific stages of patient itinerary. However, analysing how those individual stages perform in different settings and how they are influenced by policy implementation provided interesting novel results, while simultaneously highlighting gaps in Brazilian literature.

\section{Conclusions}

The performance of primary care and the regulation of acute demands, especially crisis management, seem to be the most critical aspects on the pathways of mental health care in Brazil. Several investments have been done in primary care, whose results have appeared positively in the literature: increased identification, more adequate 
treatment. However, there is still need for more improvement regarding service coverage, availability of adequate $\mathrm{MH}$ treatment and shared management of cases with specialized services. There is a variety of entrance points for the mental health subsystem for different subpopulations, and although primary care influence regulating those flows might have improved, it still has a meagre impact.

There is less evidence available about crisis and acute care, with a dearth in both descriptive reports and impact analysis of the different modes of regulating this demand in Brazil. The challenges and innovations of crisis management in the community are reported in qualitative studies in numerous Brazilian scenarios [73-76], apparently with growing consensus on the necessity of better integration between general hospital and community services [77]. The challenge, however, seems to be how to develop a well-balanced system [78] dealing simultaneously with a low coverage of type III CAPS, insufficient inpatient beds in general hospitals and a suboptimal performance of the $\mathrm{MH}$ care network, which might incur on excessive hospitalization demands.

\section{Additional files}

Additional file 1. Electronic search strategies.

Additional file 2. Inclusion and exclusion criteria

Additional file 3. Studies by year and period of mental health policy.

\section{Authors' contribution}

CEA, ROC and GT conceptualized and designed the study. CEA, PRO, MBP, ECR, $B E$ and RSC performed the literature search and screening. CEA, PRO, MBP and ECR wrote the study report. All authors participated on the data analysis. All authors read and approved the final manuscript.

\section{Author details}

${ }^{1}$ Department of Collective Health, School of Medical Sciences, University of Campinas, Campinas, Brazil. ${ }^{2}$ Department of Psychology, University Centre Unicatólica of Quixadá, Quixadá, Brazil. ${ }^{3}$ Unichristus, Fortaleza, Brazil. ${ }^{4}$ Department of Community Health, Federal University of Ceará, Fortaleza, Brazil. ${ }^{5}$ Centre for Global Mental Health, Institute of Psychiatry, Psychology and Neuroscience, King's College London, London, UK. ${ }^{6}$ Fortaleza, Ceará CEP 60125-001, Brazil.

\section{Acknowledgements}

CEA, PRO, MBP, ECR and BE received scholarships from Coordenação de Aperfeiçoamento de Pessoal de Nível Superior (CAPES). ROC received research grants from Fundação de Amparo à Pesquisa do Estado de São Paulo (FAPESP), International Development Research Centre (IDRC), Conselho Nacional de Desenvolvimento Científico e Tecnológico (CNPQ) and CAPES. GT is supported by the National Institute for Health Research (NIHR) Collaboration for Leadership in Applied Health Research and Care South London at King's College London NHS Foundation Trust. The views expressed are those of the author(s) and not necessarily those of the NHS, the NIHR or the Department of Health. GT acknowledges financial support from the Department of Health via the National Institute for Health Research (NIHR) Biomedical Research Centre and Dementia Unit awarded to South London and Maudsley NHS Foundation Trust in partnership with King's College London and King's College Hospital NHS Foundation Trust. GT is supported by the European Union Seventh Framework
Programme (FP7/2007-2013) Emerald project. GT also receives support from the National Institute of Mental Health of the National Institutes of Health under award number R01MH100470 (Cobalt study). GT is also supported by the UK Medical Research Council in relation the Emilia (MR/S001255/1) and Indigo Partnership (MR/R023697/1) awards. The views expressed in this paper are those of the authors and not necessarily those of the mentioned institutions. The mentioned institutions had no role on the studies selection, data analysis or report.

\section{Competing interests}

The authors declare that they have no competing interests.

\section{Availability of data}

The dataset used in this study is available from the corresponding author on request.

\section{Consent for publication}

Not applicable.

\section{Ethics approval and consent to participate} Not applicable.

\section{Publisher's Note}

Springer Nature remains neutral with regard to jurisdictional claims in published maps and institutional affiliations.

Received: 28 February 2018 Accepted: 11 October 2018

Published online: 31 October 2018

\section{References}

1. Goldberg D, Huxley P. Mental illness in the community: the pathway to psychiatric care. London: Tavistock Publications Ltd; 1980.

2. Pescosolido B. Illness careers and network ties: a conceptual model of utilisation and compliance. Adv Med Sociol. 1991;2:161-84.

3. Rogler L, Cortes D. Help-seeking pathways: a unifying concept in mental health care. Am J Psychiatry. 1993;150:554-61. https://doi.org/10.1176/ ajp.150.4.554.

4. Evans-Lacko S, Jarrett M, McCrone P, Thornicroft G. Clinical pathways in psychiatry. Br J Psychiatry. 2008;193:4-5. https://doi.org/10.1192/bjp. bp.107.048926.

5. Cabral ALLV, Martinez-Hemáez A, Andrade EIG, Cherchiglia ML. Itinerários terapêuticos: o estado da arte da produção científica no Brasil. Cien Saude Colet. 2011;16:4433-42.

6. Vanhaecht K, Panella M, van Zelm R, Sermeus W. An overview on the history and concept of care pathways as complex interventions. Int J Care Pathways. 2010;14:117-23. https://doi.org/10.1258/jicp.2010.010019.

7. Gater R, Jordanova V, Maric N, Alikaj V, Bajs M, Cavic T, et al. Pathways to psychiatric care in Eastern Europe. Br J Psychiatry. 2005;186:529-35. https ://doi.org/10.1192/bjp.186.6.529.

8. Gater R, Sousa DBAE, Barrientos G, Caraveo J, Chandrashekar CR, Dhadphale $\mathrm{M}$, et al. The pathways to psychiatric care: a cross-cultural study. Psychol Med. 1991;21:761-74.

9. Morgan C, Mallett R, Hutchinson G, Leff J. Negative pathways to psychiatric care and ethnicity: the bridge between social science and psychiatry. Soc Sci Med. 2004;58:739-52.

10. Sartorius N, Jablensky A, Korten A, Ernberg G, Anker M, Cooper JE, et al. Early manifestations and first-contact incidence of schizophrenia in different cultures. A preliminary report on the initial evaluation phase of the WHO Collaborative Study on determinants of outcome of severe mental disorders. Psychol Med. 1986;16:909-28.

11. Volpe U, Mihai A, Jordanova V, Sartorius N. The pathways to mental healthcare worldwide: a systematic review. Curr Opin Psychiatry. 2015;28:299-306. https://doi.org/10.1097/YCO.0000000000000164.

12. Singh SP, Grange T. Measuring pathways to care in first-episode psychosis: a systematic review. Schizophr Res. 2006;81:75-82. https://doi. org/10.1016/j.schres.2005.09.018. 
13. Anderson KK, Fuhrer R, Malla AK. The pathways to mental health care of first-episode psychosis patients: a systematic review. Psychol Med. 2010;40:1585-97. https://doi.org/10.1017/S0033291710000371.

14. International Monetary Fund. World Economic Outlook Database, October 2017. World Econ Outlook Database, Oct 2017. 2017.

15. Instituto Brasileiro de Geografica e Estatística. Estimativas de população, 2017. Estim Popul 2017. 2017. https://www.ibge.gov.br/estatisticasnovoportal/sociais/populacao.html. Accessed 1 Dec 2017.

16. World Bank. GINI index (World Bank estimate). GINI Index (World Bank Estim) 2015. https://data.worldbank.org/indicator/SI.POV.GINI?locat ions=BR. Accessed 1 Nov 2017.

17. Viacava F, Bellido JG. Health, access to services and sources of payment, according to household surveys. Cien Saude Colet. 2016;21:351-70. https ://doi.org/10.1590/1413-81232015212.19422015.

18. Cecilio LCDO, Carapinheiro G, Andreazza R. Os mapas do cuidado: o agir leigo na saúde. São Paulo: Hucitec; 2014.

19. Ministério da Saúde. E-gestor Atenção Básica: informação e gestão da Atenção Básica. 2017. https://egestorab.saude.gov.br/paginas/acessoPubl ico/relatorios/relHistoricoCoberturaAB.xhtml. Accessed 1 Dec 2017.

20. Amarante P. Loucos pela vida: a trajetória da reforma psiquiátrica no Brasil. Rio de Janeiro: Editora Fiocruz; 1995.

21. Popay J, Roberts H, Sowden A, Petticrew M, Arai L, Rodgers M, et al. Guidance on the conduct of narrative synthesis in systematic reviews: a product from the ESRC methods programme. Lancaster: Lancaster University; 2006. https://doi.org/10.13140/2.1.1018.4643.

22. Huxley P. Mental illness in the community: the Goldberg-Huxley model of the pathway to psychiatric care. Nord J Psychiatry. 1996;50:47-53. https:// doi.org/10.3109/08039489609099730.

23. Kleinman A. Patients and healers in the context of culture. Berkeley: University of California Press; 1980.

24. Paula CS, Bordin IAS, Mari JDJ, Velasque L, Rohde LA, Coutinho ESF. The mental health care gap among children and adolescents: data from an epidemiological survey from four Brazilian regions. PLOS ONE. 2014;9:e88241. https://doi.org/10.1371/journal.pone.0088241.

25. Da Silva Carneiro US, Aquino GC, Jucá VJS. Desafios da integralidade na assistência: o itinerário terapêutico de mães com sofrimento psíquico grave. Rev Psicol. 2014;5:46-57.

26. Paula CS, Nakamura E, Wissow L, Bordin IA, do Nascimento R, Leite ÁM, et al. Primary care and children's mental health in Brazil. Acad Pediatr. 2009;9:249-55. https://doi.org/10.1016/j.acap.2009.02.006.

27. Quinderé PHD, Jorge MSB, Nogueira MSL, da Costa LFA, Vasconcelos MGF. Acessibilidade e resolubilidade da assistência em saúde mental: a experiência do apoio matricial. Cien Saude Colet. 2013;18:2157-66. https ://doi.org/10.1590/S1413-81232013000700031.

28. Arce VAR, Sousa MFD, Lima MDG. A práxis da Saúde Mental no âmbito da Estratégia Saúde da Família: contribuições para a construção de um cuidado integrado. Physis Rev Saúde Coletiva. 2011;21:541-60. https:// doi.org/10.1590/s0103-73312011000200011.

29. Blay SL, Furtado A, Peluso ÉTP. Knowledge and beliefs about help-seeking behavior and helpfulness of interventions for Alzheimer's disease. Aging Ment Health. 2008;12:577-86. https://doi.org/10.1080/136078608023430 50.

30. Lucchese R, de Oliveira AGB, Conciani ME, Marcon SR. Saúde mental no Programa Saúde da Família: caminhos e impasses de uma trajetória necessária. Cad Saúde Pública. 2009;25:2033-42.

31. Fatori D, Evans-Lacko S, Bordin IA, de Paula C. Child mental health care in Brazil: barriers and achievements. Lancet. 2012;379:e16-7. https://doi. org/10.1016/S0140-6736(12)60105-6.

32. Favero-Nunes MA, dos Santos MA. Itinerário terapêutico percorrido por mães de crianças com transtorno autístico. Psicol Reflexão E Crítica. 2010;23:208-21. https://doi.org/10.1590/S0102-79722010000200003.

33. Valdanha-Ornelas ÉD, dos Santos MA. O Percurso e seus Percalços: Itinerário Terapêutico nos Transtornos Alimentares. Psicol Teor E Pesqui. 2016;32:169-79. https://doi.org/10.1590/0102-37722016012445169179.

34. Falavina OP, Cerqueira MB. Saúde mental infanto-juvenil: usuários e suas trajetórias de acesso aos serviços de saúde. Espaço Saúde. 2008:10:34-46.

35. Lauridsen EPP, Tanaka OY. Morbidade referida e busca de ajuda nos transtornos mentais na infância e adolescência. Rev Saude Publica. 1999;33:586-92. https://doi.org/10.1590/S0034-89101999000600010.

36. Mendoza-Sassi R, Béria JU, Fiori N, Bortolotto A. Prevalência de sinais e sintomas, fatores sociodemográficos associados e atitude frente aos sintomas em um centro urbano no Sul do Brasil. Rev Panam Salud Pública. 2006;20:22-8. https://doi.org/10.1590/S1020-498920060007000 03.

37. Oliveira AM, Menezes PR, Busatto GF, McGuire PK, Murray RM, Scazufca M. Family context and duration of untreated psychosis (DUP): results from the Sao Paulo Study. Schizophr Res. 2010;119:124-30. https://doi. org/10.1016/j.schres.2009.08.018.

38. Borysow IDC, Furtado JP. Access, equity and social cohesion: evaluation of intersectoral strategies for people experiencing homelessness. Rev Da Esc Enferm Da USP. 2014;48:1069-76. https://doi.org/10.1590/s0080 -623420140000700015 .

39. Campanha AM, Siu ER, Milhorança IA, Viana MC, Wang Y-P, Andrade LH. Use of psychotropic medications in São Paulo Metropolitan Area, Brazil: pattern of healthcare provision to general population. Pharmacoepidemiol Drug Saf. 2015;24:1207-14. https://doi.org/10.1002/pds.3826.

40. Pereira MDO, Sá MDC, Miranda L. Um olhar sobre a atenção psicossocial a adolescentes em crise a partir de seus itinerários terapêuticos. Cad Saude Publica. 2014;30:2145-54. https://doi.org/10.1590/0102-311×00185113.

41. Portugal CM. Entre o consultório e o terreiro: mediações, ruídos e silenciamentos nos itinerários terapêuticos de adeptos do candomblé. RECIIS. 2016;10:1-14.

42. de Carvalho MB, Val AC, Ribeiro MMF, dos Santos LG. Itinerários terapêuticos de sujeitos com sintomas anoréxicos e bulímicos. Cien Saude Colet. 2016;21:2463-74. https://doi.org/10.1590/1413-81232015218.16452015.

43. Oliveira GL, Caiaffa WT, Cherchiglia ML. Saúde mental e a continuidade do cuidado em centros de saúde de Belo Horizonte, MG. Rev Saude Publica. 2008;42:707-16. https://doi.org/10.1590/S0034-89102008005000038.

44. Corrêa GHLST, Bellato R, Araújo LFDS, Hiller M. Itinerário terapêutico de idosa em sofrimento psíquico e família. Ciência, Cuid E Saúde. 2012;10:274-83. https://doi.org/10.4025/cienccuidsaude.v10i2.10462.

45. Paes LG, Schimith MD, Barbosa TM, Righi LB. Rede de atenção em saúde mental na perspectiva dos coordenadores de serviços de saúde. Trab Educ e Saúde. 2013;11:395-409. https://doi.org/10.1590/S1981-77462 013000200008

46. Ebert M, Lorenzini E, da Silva EF. Mothers of children with autistic disorder: perceptions and trajectories. Rev Gaúcha Enferm. 2015;36:49-55. https:// doi.org/10.1590/1983-1447.2015.01.43623.

47. Wang YP, Chiavegatto Filho ADP, Campanha AM, Malik AM, Mogadouro MA, Cambraia M, et al. Patterns and predictors of health service use among people with mental disorders in São Paulo metropolitan area, Brazil. Epidemiol Psychiatr Sci. 2017;26:89-101. https://doi.org/10.1017/ S2045796016000202.

48. De Pinho LB, Hernández AMB, Kantorski LP. O discurso sobre o acolhimento e a acessibilidade nos serviços comunitários de saúde mental. Cogitare Enferm. 2009;14:612-9. https://doi.org/10.5380/ce.v14i4.16373.

49. Tomita A, Burns JK, King H, Baumgartner JN, Davis GP, Mtshemla S, et al. Duration of untreated psychosis and the pathway to care in KwaZuluNatal, South Africa. J Nerv Ment Dis. 2015;203:222-5. https://doi. org/10.1097/NMD.0000000000000268.

50. Dalgalarrondo P. Estudos sobre religião e saúde mental realizados no Brasil: histórico e perspectivas atuais. Arch Clin Psychiatry. 2007;34:25-33.

51. Ishikawa RZ, Cardemil EV, Falmagne RJ. Help seeking and help receiving for emotional distress among latino men and women. Qual Health Res. 2010;20:1558-72. https://doi.org/10.1177/1049732310369140.

52. Morgan C, Abdul-Al R, Lappin JM, Jones P, Fearon P, Leese M, et al. Clinical and social determinants of duration of untreated psychosis in the AeSOP first-episode psychosis study. Br J Psychiatry. 2006;189:446-52. https:// doi.org/10.1192/bjp.bp.106.021303

53. Bergner E, Leiner AS, Carter T, Franz L, Thompson NJ, Compton MT. The period of untreated psychosis before treatment initiation: a qualitative study of family members' perspectives. Compr Psychiatry. 2008;49:530-6. https://doi.org/10.1016/j.comppsych.2008.02.010.

54. Paula CS, Lauridsen-Ribeiro E, Wissow L, Bordin IAS, Evans-Lacko S. How to improve the mental health care of children and adolescents in Brazil: actions needed in the public sector. Rev Bras Psiquiatr. 2012;34:334-51.

55. Couto MCV, Duarte CS, Delgado PGG. A saúde mental infantil na Saúde Pública brasileira: situação atual e desafios. Rev Bras Psiquiatr. 2008:30:384-9.

56. Brzozowski FS, de Caponi SNC. Medicalização dos desvios de comportamento na infância e adolescência: aspectos positivos e negativos. Psicol Ciência E Profissão. 2013:33:208-21. 
57. Guarido R. A medicalização do sofrimento psíquico: considerações sobre o discurso psiquiátrico e seus efeitos na Educação. Educ E Pesqui. 2007;33:151-61.

58. Angermeyer MC, Matschinger H, Riedel-Heller SG. What to do about mental disorder: help-seeking recommendations of the lay public. Acta Psychiatr Scand. 2001;103:220-5. https://doi.org/10.103 4/j.1600-0447.2001.103003220.x.

59. Bland RC, Newman SC, Orn H. Help-seeking for psychiatric disorders. Can J Psychiatry. 1997:42:935-42. https://doi.org/10.1177/070674379704200 904.

60. BRASIL. Ministério da Saúde. Saúde Mental e Atenção Básica: o vínculo e o diálogo necessários. Brasília: Ministério da Saúde; 2003.

61. Brasil. Ministério da Saúde. Saúde Mental. Cad Atenção Básica 2013;34.

62. Morais APP, Tanaka OY. Apoio Matricial em Saúde Mental: alcances e limites na atenção básica. Saúde E Soc. 2012;21:161-70.

63. Figueiredo MD, Onocko-Campos R. Saúde Mental na atenção básica à saúde de Campinas, SP: uma rede ou um emaranhado? Cien Saude Colet. 2009:14:129-38

64. Miranda L, Onocko-Campos R. Análise das equipes de referência em saúde mental: uma perspectiva de gestão da clínica. Cad Saúde Pública, Rio Janeiro. 2010;26:1153-62.

65. Tófoli LF, Fortes S. Apoio matricial de saúde mental na atenção primária no município de Sobral, CE: o relato de uma experiência. Sanare, Sobral. 2007:6:34-42.

66. Craven MA, Bland R. Better practices in collaborative mental health care: an analysis of the evidence base. Can J Psychiatry. 2006;51:7S-72S.

67. Vannucchi AMC, Carneiro Junior N. Modelos tecnoassistenciais e atuação do psiquiatra no campo da atenção primária à saúde no contexto atual do Sistema Único de Saúde, Brasil. Physis. 2012;22:963-82.

68. Bezerra E, Dimenstein M. Os CAPS e o Trabalho em Rede: Tecendo o Apoio Matricial na Atenção Básica. Psicol Ciência e Profissão. 2008;28:632-45

69. Wang PS, Aguilar-Gaxiola S, Alonso J, Angermeyer MC, Borges G, Bromet EJ, et al. Use of mental health services for anxiety, mood, and substance disorders in 17 countries in the WHO world mental health surveys. Lancet. 2007;370:841-50. https://doi.org/10.1016/S0140-6736(07)61414-7.

70. Fleury M-J, Grenier G, Bamvita J-M, Caron J. Professional service utilisation among patients with severe mental disorders. BMC Health Serv Res. 2010;10:141. https://doi.org/10.1186/1472-6963-10-141.

71. Barros REM, Tung TC, Mari JDJ. Serviços de emergência psiquiátrica e suas relações com a rede de saúde mental brasileira. Rev Bras Psiquiatr. 2010;32:s71-7.

72. Jardim K, Dimenstein M. Risco e crise: pensando os pilares da urgência psiquiátrica. Psicol Em Rev. 2007;13:169-89.

73. Nicácio F, Campos GWDS. A complexidade da atenção às situações de crise: contribuições da desinstitucionalização para a invenção de práticas inovadoras em saúde mental. Rev Ter Ocup Da Univ São Paulo. 2004;15:71-81. https://doi.org/10.11606/issn.2238-6149.v15i2p71-81.

74. Willrich JQ, Kantorski LP, Chiavagatti FG, Cortes JM, Antonacci MH. Os sentidos construídos na atenção à crise no território: o Centro de Atenção Psicossocial como protagonista. Rev Da Esc Enferm Da USP. 2013;47:65763. https://doi.org/10.1590/S0080-623420130000300019.

75. Onocko-Campos R, Furtado JP, Passos E, Ferrer AL, Miranda L, da Gama CAP. Avaliação da rede de centros de atenção psicossocial: entre a saúde coletiva e a saúde mental. Rev Saude Publica. 2009;43:16-22. https://doi. org/10.1590/S0034-89102009000800004.

76. Dimenstein M, Amorim AKA, Leite J, Siqueira K, Gruska V, Vieira C, et al. $\mathrm{O}$ atendimento da crise nos diversos componentes da rede de atenção psicossocial em Natal/RN. Rev P Psique. 2012;2:95-127.

77. Dias M, Golçalves RW, Delgado PGG. Leitos de atenção integral à saúde mental em hospital geral: configuração atual e novos desafios na política de saúde mental. In: Vasconcelos EM, editor. Desafios políticos da reforma psiquiátrica Bras. São Paulo: Hucitec; 2010. p. 115-40.

78. Thornicroft G, Tansella M. Balancing community-based and hospitalbased mental health care. World Psychiatry. 2002;1:84-90.
Ready to submit your research? Choose BMC and benefit from:

- fast, convenient online submission

- thorough peer review by experienced researchers in your field

- rapid publication on acceptance

- support for research data, including large and complex data types

- gold Open Access which fosters wider collaboration and increased citations

- maximum visibility for your research: over 100M website views per year

At BMC, research is always in progress.

Learn more biomedcentral.com/submissions 